\title{
SLAUGHTER CHARACTERISTICS OF LAMB'S MEAT ACCORDING TO BREEDING SYSTEMS
}

\author{
Tatjana Kalevska $^{1}$, Ljupche Kochoski ${ }^{2}$, Elena Joshevska ${ }^{2}$, Zora Uzunoska ${ }^{1}$, Viktorija Stamatovska ${ }^{1}$ \\ ${ }^{1}$ St." Kliment Ohridski" University. Faculty of Technology and Technical Sciences, \\ Dimitar Vlahov bb. 1400 Veles. Republic of Macedonia \\ ${ }^{2}$ St."Kliment Ohridski" University. Faculty of Biotechnical Sciences. \\ Partizanska bb, 7000 Bitola. Republic of Macedonia \\ tkalevska@gmail.com
}

\begin{abstract}
The aim of this research was to determine how breeding systems (organic and conventional) influence the growth intensity and carcass traits of lamb meat. The research was carried out on 120 lambs, of which 60 were reared in a conventional and 60 in an organic system, in a period of 75 days. The lambs from the organic system were bred according to the regulations on organic farming, while the lambs from the conventional system were bred in a traditional way. The results show differences in birth weight of lambs from organic (3.991-4.189 kg) and conventional breeding systems $(4.226-4.338 \mathrm{~kg})$. There are no significant differences $(\mathrm{p}>0.05)$ in the body weight prior to slaughter and in the average daily gain between the groups. After the slaughter, measurements of each carcass were done. The differences in the dressing percentage of the lambs between the groups from organic and conventional production are not statistically significant $(\mathrm{p}>0.05)$.
\end{abstract}

Key words: lambs; breeding systems; slaughter; quality; carcasses

\section{КЛАНИЧНИ КАРАКТЕРИСТИКИ НА МЕСОТО ОД ЈАГНИЬА ВО ЗАВИСНОСТ ОД СИСТЕМОТ НА ОДГЛЕДУВАЫЕ}

\begin{abstract}
Цел на ова истражување беше да се утврди како влијае системот на одгледување (органски и конвенционален) врз прирастот и кланичните особини на месото од јагниња. Истражувањето беше спроведено на 120 јагниња, од кои 60 беа одгледувани во конвенционален и 60 во органски систем во период од 75 дена. Јагнињата од органскиот систем се одгледуваа во согласност со прописите за органско земјоделско производство, додека јагниња од конвенционалниот систем се одгледуваа на традиционален начин. Резултатите покажуваат разлики во породната маса на јагнињата од органскиот $(3,991-4,189 \mathrm{~kg})$ и конвенционалниот систем на одгледување $(4,226-4,338 \mathrm{~kg})$. Не постои значајна разлика $(\mathrm{p}>0,05)$ во телесната маса пред колење и просечниот прираст помеѓу двете групи. По колењето беа направени мерења на секој труп, со цел да се утврдат одредени кланични резултати. Рандманот на колење на јагнињата меѓу групите од органското и конвенционалното производство не е статистички значаен ( $\mathrm{p}>0,05)$.
\end{abstract}

Клучни зборови: јагниња; систем на одгледување; колење; квалитет; заклани трупови

\section{INTRODUCTION}

The lamb meat is a high-quality product, used by consumers from all over the world, from different cultures and religions. Due to the increase in the interest and the needs of the domestic and foreign markets for lamb, there are demands for increasing its quality, covered by the new EU regulations concerning the quality of the animals for breeding (Zujović, 2004). According to Osamu et al. (2005), there is no general model for breeding, which could be applied in all farms and in all conditions. There are different breeding systems in the world that are conditioned by natural and economic factors, as 
well as by the tradition of the countries or regions. In the conventional system, the traditional way of breeding is popular, with the technology of early weaning of the lambs 25 to 30 days after birth as well as intensive feeding with concentrated feed mixture and hay at will up to a certain slaughter weight or age.

The main goal of this kind of breeding is intensification of sheep breeding, by achieving good fattening performances in the early weaned lambs and obtaining a greater amount of milk per sheep (Pacinovski et al., 2011). Compared to conventional, organic sheep production is based on the compliance with the standards and legal regulations in the control of each stage of the production cycle, and which contribute to the animals' welfare and the production of safe products of animal origin.

The breeding of lambs in an organic system is carried out in accordance with the organic production rules equivalent to the European Union Regulation 834/2007, according to which, in order to respect animals' welfare, the lambs should be weaned at the age of 45 days. Lambs grown in conventional and organic systems have similar production and slaughtering yields (Fisher et al., 2000).

The type of diet and the composition of the meal are the basic factors of the external environment that determine the success of lambs' fattening (Grubić et al., 1991). The lambs' diet must be tailored to the age of the heads, the planned intensity of fattening and the desired body weight at the time of their sale (Zeremski et al., 1989). The animals' nutrition in the organic system is one of the most important factors that influence the quality of the meat and constitutes the most important basis on which depends the success of organic meat production (Kerry et al., 2000).

\section{MATERIAL AND METHODS}

The research was carried out on 120 lambs, of which 60 were bred in a conventional and 60 in an organic system for a period of 75 days. In both systems of breeding, two groups of lambs were formed, each with 30 lambs: group I, made up of crossbreeds of domestic Merino breed refined with Virtemberg breed; and group II, made up of crossbreeds of domestic Merino breed refined with East-Friesian breed.

The lambs from the organic system were bred according to the regulations for organic farming, while the lambs from the conventional system were bred in a traditional way. The lambs from both systems were bred in separate, physically divided and marked spaces on the farm, and in on-the-ground way with the use of deep layer of straw.

In the conventional system, the sucking ended at the $30^{\text {th }}$ day, and thereafter they were fed with conventional commercial fodder (20\% of corn, $20 \%$ of wheat, $30 \%$ of barley, $28 \%$ of peas, $1 \%$ of premix, $0.6 \%$ of feed chalk and $0.4 \%$ of salt), alfalfa hay and ad libitum water.

In the organic system, the lambs were bred in compliance with the rules prescribed in EU Reg. $834 / 2007$, according to which, in order to provide for the animals' welfare, the lambs were weaned at the $45^{\text {th }}$ day after birth and further fed with concentrated fodder produced from organic and certified feed, in an own mill.

The chemical composition of the conventional and organic feed mixtures is presented in Table 1. The energy and protein values of the both feed mixtures are almost identical.

Table 1

\section{Chemical composition of the feed mixture for lambs from the conventional and the organic system}

\begin{tabular}{lcc}
\hline \hline Indicators (\%) & Conventional system & Organic system \\
\hline Moisture & 15.44 & 14.98 \\
Dry matter & 84.56 & 85.02 \\
Raw proteins & 14.86 & 14.76 \\
Raw fats & 1.21 & 1.20 \\
Raw fiber & 3.63 & 3.96 \\
Raw ash & 4.92 & 3.81 \\
$*$ NFE & 59.94 & 61.29 \\
Calcium & 2.20 & 1.20 \\
Phosphorus & 0.38 & 0.35 \\
\hline \hline
\end{tabular}

*Nitrogen -free extractive substances

The control of the body weight of the lambs from both systems has been performed every fifteen days, i.e. on day $1,15,30,45,60$ and 75 . During the research, the lambs' daily and total increment were determined, as well as the daily and total feed consumption per lamb and the feed conversion for $1 \mathrm{~kg}$ of growth. In determining the slaughter value, the following categories of lambs' carcass based on dressing percentage were defined: warm carcass with head and viscera (R I); cold carcass with head and viscera (R II); cold carcass with head but without viscera (R III); cold carcass without head and without viscera (R IV). 


\section{RESULTS AND DISCUSSION}

The dynamics of the body weight of the lambs from the organic and conventional systems from the partus to the end of the breeding is presented in Table 2 .

Table 2

Dynamics of body weight of lambs from the organic and the conventional system

\begin{tabular}{|c|c|c|c|c|c|c|}
\hline Days & $\bar{x}$ & $\mathrm{Sd}$ & $\mathrm{cv}$ & $S \bar{x}$ & $\min$ & $\max$ \\
\hline & \multicolumn{6}{|c|}{$\mathrm{O}(\mathrm{I})$} \\
\hline Birth weight & 3.991 & 0.522 & 13.08 & 0.095 & 3.080 & 4.970 \\
\hline 15 days & 6.189 & 0.904 & 14.61 & 0.165 & 4.190 & 7.900 \\
\hline 30 days & 8.335 & 1.375 & 16.49 & 0.248 & 5.270 & 11.230 \\
\hline 45 days & 11.640 & 1.386 & 11.90 & 0.251 & 8.210 & 14.700 \\
\hline 60 days & 14.990 & 1.687 & 11.25 & 0.308 & 9.250 & 16.830 \\
\hline \multirow[t]{2}{*}{75 days } & 17.995 & 1.812 & 10.07 & 0.331 & 13.215 & 19.900 \\
\hline & \multicolumn{6}{|c|}{$\mathrm{O}(\mathrm{II})$} \\
\hline Birth weight & 4.189 & 0.566 & 13.52 & 0.103 & 3.270 & 4.990 \\
\hline 15 days & 6.405 & 0.963 & 15.04 & 0.176 & 4.630 & 7.970 \\
\hline 30 days & 8.547 & 1.564 & 18.30 & 0.286 & 5.415 & 11.420 \\
\hline 45 days & 11.826 & 1.747 & 14.77 & 0.318 & 8.690 & 15.890 \\
\hline 60 days & 15.073 & 2.387 & 15.83 & 0.436 & 11.630 & 18.470 \\
\hline \multirow[t]{2}{*}{75 days } & 18.363 & 2.161 & 11.77 & 0.395 & 13.430 & 22.190 \\
\hline & \multicolumn{6}{|c|}{$\mathrm{C}(\mathrm{I})$} \\
\hline Birth & 226 & 0.615 & 1 & 0.112 & 15 & 5.090 \\
\hline 15 days & 6.466 & 0.980 & 15.15 & 0.179 & 4.760 & 8.260 \\
\hline 30 days & 8.451 & 1.753 & 16.99 & 0.320 & 5.040 & 12.180 \\
\hline 45 days & 12.117 & 2.539 & 20.51 & 0.463 & 7.120 & 16.030 \\
\hline 60 days & 15.142 & 2.799 & 18.48 & 0.511 & 9.915 & 20.730 \\
\hline \multirow[t]{2}{*}{75 days } & 18.480 & 2.447 & 13.24 & 0.452 & 13.745 & 23.980 \\
\hline & \multicolumn{6}{|c|}{$\mathrm{C}(\mathrm{II})$} \\
\hline Birth weight & 4.338 & 0.561 & 12.95 & 0.102 & 3.395 & 5.125 \\
\hline 15 days & 6.732 & 0.896 & 13.31 & 0.164 & 4.890 & 8.470 \\
\hline 30 days & 8.859 & 1.633 & 18.86 & 0.298 & 5.690 & 11.640 \\
\hline 45 days & 12.358 & 2.166 & 17.53 & 0.395 & 8.100 & 18.155 \\
\hline 60 days & 15.939 & 2.567 & 16.11 & 0.469 & 11.810 & 23.400 \\
\hline 75 days & 19.149 & 2.339 & 12.22 & 0.428 & 14.910 & 26.680 \\
\hline
\end{tabular}

The birth weight is the basis for further growth and development of lambs (Petrović et al., 2009). The average birth weight of the lambs from group I in the organic system was $3.991 \mathrm{~kg}$, and $4.189 \mathrm{~kg}$ from group II. Similar birth weights of $4.226 \mathrm{~kg}$ and $4.338 \mathrm{~kg}$ were found in the lambs from groups I and II, respectively, in the conventional system. Regarding birth weight, no statistically significant difference was found between the groups of lambs in the organic system and between the groups in the conventional system. Also, the difference found in birth weight between the lambs from groups I in the organic and conventional systems, as well as the difference between the lambs from groups II in the organic and conventional systems, are statistically not significant $(p>0.05)$. Similar results were found by Pacinovski et al. (2011). At the end of the breeding on day 75 , the highest body weight of $19.149 \mathrm{~kg}$ was reached by the lambs from group II in the conventional system, and the lowest body weight of 17.995 $\mathrm{kg}$ by the lambs from group I in the organic system. Our results regarding the body weight of the lambs in the organic system at the end of the breeding are similar with the results obtained by Morbidini et al. (2001). The differences in the body weight of the lambs found at the end of the breeding between the groups in the same system, as well as the differences between the respective groups in different systems (organic and conventional system) are statistically not significant $(p>0.05)$. The data on the growth of the lambs in the organic and the conventional system at certain periods of breeding are shown in Tables 3 and 4 ..

Table 3

Growth of lambs from groups I and II in the organic and the conventional system, at certain periods of breeding

\begin{tabular}{|c|c|c|c|c|c|}
\hline & Days & $\bar{x}$ & $S_{d}$ & $\mathrm{cv}$ & $S \bar{x}$ \\
\hline \multirow{5}{*}{$\mathrm{O}(\mathrm{I})$} & $1-15$ & 2.199 & 0.383 & 17.43 & 0.06 \\
\hline & $15-30$ & 2.146 & 0.448 & 20.88 & 0.08 \\
\hline & $30-45$ & 3.305 & 0.511 & 15.47 & 0.09 \\
\hline & $45-60$ & 3.350 & 0.371 & 11.09 & 0.06 \\
\hline & $60-75$ & 3.005 & 0.430 & 14.31 & 0.08 \\
\hline \multirow{5}{*}{$\mathrm{O}$ (II) } & $1-15$ & 2.225 & 0.399 & 17.96 & 0.07 \\
\hline & $15-30$ & 2.142 & 0.406 & 18.93 & 0.07 \\
\hline & $30-45$ & 3.279 & 0.534 & 16.29 & 0.09 \\
\hline & $45-60$ & 3.247 & 0.511 & 15.61 & 0.09 \\
\hline & $60-75$ & 3.290 & 0.474 & 14.42 & 0.09 \\
\hline \multirow{5}{*}{$\mathrm{C}(\mathrm{I})$} & $1-15$ & 2.240 & 0.434 & 19.38 & 0.07 \\
\hline & $15-30$ & 1.985 & 0.347 & 17.48 & 0.06 \\
\hline & $30-45$ & 3.666 & 0.528 & 14.42 & 0.09 \\
\hline & $45-60$ & 3.026 & 0.588 & 19.40 & 0.10 \\
\hline & $60-75$ & 3.338 & 0.635 & 19.02 & 0.11 \\
\hline \multirow{5}{*}{ C(II) } & $1-15$ & 2.394 & 0.522 & 21.80 & 0.09 \\
\hline & $15-30$ & 2.127 & 0.379 & 17.82 & 0.07 \\
\hline & $30-45$ & 3.499 & 0.596 & 17.04 & 0.11 \\
\hline & $45-60$ & 3.581 & 0.490 & 13.69 & 0.08 \\
\hline & $60-75$ & 3.210 & 0.568 & 17.69 & 0.10 \\
\hline
\end{tabular}


Table 4

Total and daily lambs' growth from the organic and the conventional system

\begin{tabular}{|c|c|c|c|c|}
\hline \multirow[b]{2}{*}{ Day } & \multicolumn{4}{|c|}{ Growth } \\
\hline & $\begin{array}{c}\text { Total } \\
\mathrm{kg}\end{array}$ & $\begin{array}{c}\text { Daily } \\
\mathrm{g}\end{array}$ & $\begin{array}{c}\text { Total } \\
\mathrm{kg}\end{array}$ & $\begin{array}{c}\text { Daily } \\
\mathrm{g}\end{array}$ \\
\hline & \multicolumn{2}{|c|}{$\mathrm{O}(\mathrm{I})$} & \multicolumn{2}{|c|}{$\mathrm{O}$ (II) } \\
\hline $1-15$ & 2.199 & 148 & 2.225 & 148 \\
\hline $15-30$ & 2.146 & 143 & 2.142 & 143 \\
\hline $30-45$ & 3.305 & 220 & 3.279 & 219 \\
\hline $45-60$ & 3.350 & 223 & 3.247 & 216 \\
\hline $60-75$ & 3.005 & 200 & 3.290 & 219 \\
\hline \multirow[t]{2}{*}{$\sum 1-75$} & 14.005 & 186.8 & 14.183 & 189 \\
\hline & \multicolumn{2}{|c|}{$\mathrm{C}(\mathrm{I})$} & \multicolumn{2}{|c|}{$\mathrm{C}(\mathrm{II})$} \\
\hline $1-15$ & 2.240 & 149 & 2.394 & 160 \\
\hline $15-30$ & 1.985 & 132 & 2.127 & 142 \\
\hline $30-45$ & 3.666 & 244 & 3.499 & 233 \\
\hline $45-60$ & 3.026 & 202 & 3.581 & 239 \\
\hline $60-75$ & 3.338 & 222 & 3.210 & 214 \\
\hline$\sum 1-75$ & 14.255 & 189.8 & 14.811 & 197.6 \\
\hline
\end{tabular}

The highest value of the total and the daily growth in the period from day 45 to day 60 was noted in the lambs from group I in the organic $(3.350 \mathrm{~kg}$ and $223 \mathrm{~g}$ ) and group II in the conventional system $(3.581 \mathrm{~kg}$ and $239 \mathrm{~g})$; in the period from day 60 to day 75 - in the lambs from group II in the organic system $(3.290 \mathrm{~kg}$ and $219 \mathrm{~g})$; and in the period from day 30 to day 45 in the lambs from group I in the conventional system $(3.666 \mathrm{~kg}$ and $244 \mathrm{~g}$ ). The lowest growth of the lambs in both systems was achieved in the period from day 15 to day 30 when the exterior temperatures were extremely low, thereby a conclusion can be drawn that the season has a certain influence on lambs' growth in some periods of their breeding. Our conclusion coincides with the conclusion drawn by Hahn et al. (1987), that the lower growth of lambs is due to extremely low temperatures which negatively affect the consumption of feed per head.

The total growth from day 1 to day 75 , in the lambs from groups I and II in the organic system is $14.005 \mathrm{~kg}$ and $14.183 \mathrm{~kg}$, respectively, while in the lambs from the groups I and II in the conventional system is $14.255 \mathrm{~kg}$ and $14.811 \mathrm{~kg}$, respectively. In the period from weaning until the end of the breeding in the organic system (i.e. from day 45 to day 75 ), the daily growth of the lambs from groups I and
II is 211 grams and 217 grams, respectively, while in the conventional system during the period from the weaning to the end of the breeding (i.e. from day 30 to day 75) the daily growth is $222 \mathrm{~g}$ in the lambs from group I and $228 \mathrm{~g}$ in group II. The average daily growth (i.e. from day 1 to day 75) of the lambs from groups I and II in the organic system is 186.8 $\mathrm{g}$ and $189 \mathrm{~g}$, respectively. The average daily growth of the lambs in the conventional system is $189.8 \mathrm{~g}$ in group I and $197.6 \mathrm{~g}$ in group II. The differences in the total and the daily growth between the groups in the same breeding system, i.e. between $\mathrm{O}$ (I) and $\mathrm{C}$ (I) as well as $\mathrm{O}$ (II) and C (II), are not statistically significant ( $\mathrm{p}>0.05)$. Results approximate to ours on the total and the daily growth were reported by Kozarovski (1988). Also, results similar to ours on the average daily growth were found by Danev (1984) in the lambs from the group A. Lower values for the growth compared to ours, which are due to the breed's characteristics, were registered by Hanoglu et al. (2013) in lambs of autochthonous Turkish breeds grown in both organic and conventional systems, while Cmiljanić et al. (2003) in their studies registered higher growth values than we did.

The total and daily consumption of feed by lamb in the organic and conventional systems are presented in Table 5 .

Table 5

Total and daily consumption of food by lamb in the organic and the conventional system

\begin{tabular}{lcccc}
\hline \hline & Total & Daily & Total & Daily \\
\hline Organic system & \multicolumn{2}{c}{ Group I } & \multicolumn{2}{c}{ Group II } \\
30-45 day & 2.906 & 194.0 & 3.065 & 204.0 \\
45-60 day & 8.037 & 536.0 & 8.394 & 559.6 \\
60-75 day & 9.890 & 659.0 & 10.298 & 686.5 \\
$\Sigma \bar{x}$ 30-75 day & 20.833 & 463.0 & 21.757 & 483.3 \\
\hline Conventional system & Group I & Group II \\
\hline $30-45$ day & 5.992 & 399.0 & 6.389 & 425.9 \\
$45-60$ day & 7.911 & 527.4 & 8.285 & 552.0 \\
$60-75$ day & 10.480 & 692.0 & 10.670 & 711.0 \\
$\Sigma \bar{x}$ 30-75 day & 24.383 & 539.4 & 25.344 & 562.9 \\
\hline \hline
\end{tabular}

During the entire research period (from day 30 to day 75), the total amount of consumed feed by the lambs from the organic system was $20.833 \mathrm{~kg}$ per lamb, or $24.383 \mathrm{~kg}$ in the conventional system. The 
lowest consumption of feed mixture per lamb in the organic system was found in the period from day 30 to day $45(2.906 \mathrm{~kg})$, which was expected because in that period the lambs also received milk from their mothers in addition to the feed mixture. The highest consumption of food was in the period from day 60 to day $75(9.890 \mathrm{~kg})$, when the lambs were oldest (Gutić et al., 2006).

In the lambs from the conventional system, the lowest consumption was observed in the period from day 30 to day $45(5.992 \mathrm{~kg})$, and the highest in the period from day 60 to day $75(10.480 \mathrm{~kg})$. The established differences in the total consumption of feed between lambs from groups I in the organic and the conventional systems, as well as between lambs from groups II in both systems, are statistically significant $(\mathrm{p}<0.01)$. These differences are due to the technology, namely - the system of breeding lambs practiced in the organic system, i.e. the weaning of the lambs on the $45^{\text {th }}$ day, in contrast to the lambs in the conventional system that were weaned on the $30^{\text {th }}$ day.

The differences in the daily consumption of feed between the lambs from groups I in the organic and conventional systems, as well as between groups II in both systems, are statistically significant $(\mathrm{p}<0.01)$ and are also due to the different breeding technologies. Higher average values for total and daily consumption of feed for the entire experimental period were presented by Pacinovski et al. (2011), while higher values for the average daily consumption than those we have obtained, were presented by Hanoglu et al. (2013).

The profitability of the production of lamb is conditioned by the conversion of feed, i.e. by the average consumption of food for $1 \mathrm{~kg}$ of growth (Gutić et al., 2006). In the period from day 30 to day 75 , the average consumption of feed for $1 \mathrm{~kg}$ of growth in the lambs from group I in the organic system is $2.189 \mathrm{~kg}$, and $2.216 \mathrm{~kg}$ in group II.

The average consumption of feed for $1 \mathrm{~kg}$ of growth in the conventional system for lambs from group I is 2.472 , and $2.488 \mathrm{~kg}$ in group II. In lambs of domestic merinized sheep (Pacinovski et al., 2011), the feed conversion was estimated to be 3.65 $\mathrm{kg}$ and $3.90 \mathrm{~kg}$ for the lambs from groups I and II, respectively, depending on the lambs' diet and the breeding technolog.

The lamb's weight before slaughter affects the slaughtering weight of the lamb's carcass. The average slaughtering weight of lambs (Table 6) from group I in the organic system is $16.987 \mathrm{~kg}$, and $17.267 \mathrm{~kg}$ for lambs from group II, while the lamb's slaughter weight in the conventional system is $17.368 \mathrm{~kg}$ for lambs from group I, and $17.792 \mathrm{~kg}$ from group II.

Table 6

Lamb slaughtering weight from the organic and the conventional system

\begin{tabular}{ccccc}
\hline \hline $\begin{array}{c}\text { Lamb slaughtering } \\
\text { weight }\end{array}$ & $\bar{x}$ & $\mathrm{Sd}$ & $\mathrm{cv}$ & $\mathrm{S} \bar{x}$ \\
\hline $\mathrm{O}$ (I) & 16.987 & 1.772 & 10.430 & 0.314 \\
$\mathrm{O}$ (II) & 17.267 & 2.125 & 12.308 & 0.388 \\
$\mathrm{C}$ (I) & 17.368 & 2.934 & 16.894 & 0.535 \\
$\mathrm{C}$ (II) & 17.792 & 3.133 & 17.611 & 0.572 \\
\hline \hline
\end{tabular}

The observed differences in the slaughtering weight of lambs from the groups in both systems are statistically not significant ( $p>0.05)$, which is expected since the lambs' weight in both breeding systems before slaughter is nearly the same.

The dressing percentage of slaughtering is highly variable and depends on the influence of several factors such as breed, sex, age, diet, degree of fattening, etc.. During the research, between the lambs from groups I from the organic and the conventional system, a difference was found in the dressing percentage for the category R I of $0.89 \%$, for R II of $0.84 \%$, for R III of $0.65 \%$, and for R IV of $0.59 \%$; as well as differences in the dressing percentage between the lambs from groups II in the organic and the conventional system, for the category R I of $0.74 \%$, for R II of $0.40 \%$, for R III of $0.24 \%$, and for R IV of $0.23 \%$. The discrepancies in the average value of the dressing percentage for the lambs from groups I in the organic and the conventional system and groups II from both systems are statistically not significant in all cases ( $p>0.05$ ), which is understandable, because the live weight of lambs and slaughter weight of lamb carcasses from the organic and conventional systems are very close ( $\mathrm{Ta}-$ ble 7). Morbidini et al. (2001) found similar results to ours regarding the dressing percentage of warm carcasses in lambs bred in the organic system of $51.66 \%$ and of $48.90 \%$ in lambs from the control group. The smaller dressing percentage values in lambs from the control group according to the authors are probably due to earlier weaning, changes in lambs' diet, and the stress they experience during transportation. Hanoglu et al. (2013) reported values for the dressing percentage of warm carcasses which deviate from the values we found, namely - 
in the lambs from the conventional system of 49.27 \pm 0.607 , and $49.36 \pm 0.525$ in the lambs from the organic system. In the research of the slaughtering indicators in Creska lambs, Mioč et al. (2009) registered values close to ours, namely - slaughtering weight of lambs of $19.04 \mathrm{~kg} \pm 0.22$ and a dressing percentage of $50.50 \pm 0.60$.

Table 7

Dressing percentage of lambs' slaughtering from the organic and the conventional system

\begin{tabular}{|c|c|c|c|c|c|}
\hline $\begin{array}{l}\text { Dressing } \\
\text { percentage }\end{array}$ & $\bar{x}$ & $S_{d}$ & $\mathrm{Cv}$ & $\min$ & $\max$ \\
\hline $\mathrm{O}(\mathrm{I})-\mathrm{R} \mathrm{I}$ & 53.98 & 1.359 & 2.518 & 51.89 & 56.54 \\
\hline $\mathrm{O}(\mathrm{I})-\mathrm{R}$ II & 52.84 & 1.301 & 2.463 & 50.59 & 55.11 \\
\hline $\mathrm{O}(\mathrm{I})-\mathrm{R}$ III & 48.19 & 1.681 & 3.490 & 45.88 & 50.46 \\
\hline $\mathrm{O}(\mathrm{I})-\mathrm{R}$ IV & 43.90 & 1.642 & 3.740 & 41.59 & 46.17 \\
\hline $\mathrm{O}(\mathrm{II})-\mathrm{R}$ I & 54.95 & 1.249 & 2.274 & 52.41 & 56.65 \\
\hline $\mathrm{O}(\mathrm{II})$ - R II & 53.67 & 1.210 & 2.256 & 51.13 & 55.37 \\
\hline $\mathrm{O}(\mathrm{II})$ - R III & 48.77 & 1.330 & 2.272 & 46.23 & 50.47 \\
\hline $\mathrm{O}(\mathrm{II})$ - R IV & 44.34 & 1.284 & 2.896 & 41.89 & 45.97 \\
\hline$C(I)-R ~ I$ & 54.87 & 0.857 & 1.563 & 53.64 & 56.16 \\
\hline$C(I)-R ~ I I ~$ & 53.68 & 1.082 & 2.017 & 51.14 & 55.64 \\
\hline$C(\mathrm{I})-\mathrm{R}$ III & 48.84 & 1.276 & 2.614 & 46.29 & 50.83 \\
\hline $\mathrm{C}(\mathrm{I})-\mathrm{R}$ IV & 44.49 & 1.488 & 3.346 & 42.21 & 48.16 \\
\hline $\mathrm{C}(\mathrm{II})-\mathrm{R} \mathrm{I}$ & 55.69 & 1.052 & 1.889 & 53.62 & 57.68 \\
\hline C(II) - R II & 54.07 & 1.029 & 1.904 & 52.02 & 55.72 \\
\hline C(II) - R III & 49.01 & 1.087 & 2.218 & 47.02 & 51.38 \\
\hline C(II) - R IV & 44.57 & 1.208 & 2.710 & 42.66 & 47.32 \\
\hline
\end{tabular}

\section{CONCLUSION}

Based on the goals set and the results obtained, the following conclusions can be made:

The differences observed in the production results (birth weight, body mass and growth) of lambs throughout the entire breeding period were not statistically significant $(p>0.05)$ between any of the groups bred in an organic and a conventional system. As a result of the way of breeding and feeding the lambs in accordance with the EU Reg. 834/2007 in the organic system, a lower consumption of feed was found_compared to the conventional system. During the entire breeding period of the lambs from both systems, there has been a constant increase in the consumption of feed, corresponding to the increase in the age of the lambs. The differences found in the slaughter parameters (slaughtering weight, dressing percentage for R I, R II, R III and R IV) are not statistically significant between lambs bred in the organic and the conventional system $(\mathrm{p}>0.05)$.

The results obtained in this research allow us to make the conclusion that lambs bred in an organic and a conventional system have similar production and slaughtering yields.

\section{REFERENCES}

[1] Cmiljanić R., Žujović M., Trenkoski S., Pavlovski Z.: Uticaj tipa ishrane na proizvodne rezultate kod jagnjadi u tovu. Biotechnology in Animal Husbandru 19 (3-4), pp. 188 (2003).

[2] Danev M.: Ispitivanje uticaja načina tova jagnjadi na randman klanja i neka kvalitetna svojstva mesa. Doktorska disertacija. Veterinarski fakultet. Univerzitet u Beogradu, 1984.

[3] European Organic Regulation (EC) No 834/2007.

[4] Fisher AV, Enser M, Richardson RI, Wood JD, Nute GR, Kurt E, Sinclair LA, Wilkinson RG.: Fatty acid composition and eating quality of lamb types derived from four diverse breed x production system. Meat Sci. 55, 141-147 (2000).

[5] Grubić G., Zeremski $\quad$ D., Pavličević A.: Uticaj razgradivosti proteina hrane na proizvodne rezultate odlučene jagnjadi. Zbornik radova. Poljoprivrednog fakulteta, Beograd, godina3 6, sveska 595, 169-183 (1991).

[6] Gutić M., Petrović M., Bogosavljević-Bošković S.: Ovčarstvo - tehnologija proizvodnje, str. 82-86. Agronomski fakultet, Čačak, Srbija, 2006.

[7] Hahn G. L., Schanbacher, B. D., Nienaber, J. A.: Performance-related responses of lambs to changes in environmental temperature and daylength, Livest. Prod. Sci. 16 (1), 37-49 (1987).

[8] Hanoğlu Hülya, İbrahim Ak, Deniz Soysal: Determination of organic lamb fattening performanceand slaughter caracteristics in the sout Marmara conditions in Turkey. Macedonian Journal of Animal Science, Vol. 3, No. 2, pp. 135142 (2013).

[9] Hermansen J. E.: Organic livestock production systems and appropriate development in relation to public expectations. Livestock Production Science Volume 80, Issues 12, Pages 3-15 (2003).

[10] Kerry J. P., Buckley D. J., Morrissey, P. A.: Improvement of oxidative stability of beef and lamb with vitamin. In: Antioxidants in muscle foods, nutritional strategies to improve quality. E. Decker, C. Faustman, C. J. Lopez-Bote (eds.), United States: Wiley, 2000, pp. 229 - 261.

[11] Kozarovski N.: The influence of degradability on the nutritional value of protein in the feeding of fattening lamb. Doctoral thesis. Novi Sad, 1988.

[12] Mioč B., Paviš V., Vnuţec I., Prpiš Z., Suńiš V., Baraš Z.: Klaoniçki pokazatelji i odlike trupa creske janjadi. 44th Croatian \& 4th International Symposium on Agriculture. February 16 - 20, 2009. Opatija, Croatia.

[13] Morbidini L., Pollidori P., Sarti D. M., Valigi A.: Carcass, meat and fat quality in Italian Merino derived lambs 
obtained with "organic" farming systems. In: CIHEAM, 2001, pp. 29-33.

[14] Osamu S., Kazuo I., Yoshitaka N.: Breeds and Breeding systems of dairy sheep in the Mediterranean countries. Experimental Herbivora, 29, 39-48 (2005).

[15] Pacinovski N., Eftimova E., Gorgovska N., Dubrova Mateva N., Naletoski Z., Palasevska A.: Production results of early weaned lambs from domestic merinized sheep in Macedonia. Journal of Mountain Agriculture on the Balkans, Vol. 14 (1), 76-89, Troyan, Bulgaria (2011).

[16] Petrović M., Ružić - Muslić D., Maksimović N., Memiši $\mathrm{N}$.: Effect of environmental and paragenetic factors on birth mass variability of mis populations. Biotechnology in Animal Husbandry 25 (3-4), pp. 213-219 (2009), ISSN 1450-9156.

[17] Zeremski D., Pavličević A., Grubić G.: Uticaj sastava obroka na efikasnost tova jagnjadi i šilježadi. Zbornik naučnog skupa o ishrani ovaca, Palić, 1989, pp. 115-127.

[18] Žujović M., Tomić Z., Pavlovski Z., Lukić M., Pavlović M., Ivanović S.: Randman mesa jagnjadi meleza pirotske pramenke i merino landšaf rase kao pokazatelj proizvodnje mesa. Biotechnology in Animal Husbandru. 20 (1-2), pp. 75-80 (2004). 
